\title{
The Effectiveness of EU law \\ Insights from the EU Legal Framework on Asset Confiscation
}

Dr Mihaly Fazekas, Post-Doctoral Research Fellow, Department of Sociology, University of Cambridge, UK.

Dr Eva Nanopoulos, Lecturer \& Fellow in Law, King's College, University of Cambridge, UK.*

\begin{abstract}
Based on an institutional and legal mapping of the field across Europe, this article explores the different barriers to the effectiveness of the EU's regime on the recovery and confiscation of proceeds of crime. The aim is to provide a better understanding of the challenges that arise in this field and suggest possible areas of legal or policy intervention. But it is also - using the example of asset confiscation - to contribute to debates about the effectiveness of the EU's legal strategy in building a genuine area of freedom, security and justice. The article argues that, despite the adoption of new legislation in this field and the stronger institutional framework introduced by the Treaty of Lisbon, the effectiveness of the EU's action is unlikely to significantly improve. The legal rules still present a number of deficiencies and the emphasis on formal legal solutions has come at the expense of broader questions of transposition and utilisation, which are however crucial to ensuring effective recovery.
\end{abstract}

Key words: Asset confiscation; EU; utilisation; effectiveness; legal and institutional barriers. 


\section{Introduction}

In recent decades, the confiscation and recovery of criminal assets has assumed a prominent position in the fight against organised and other profit-driven crime. While the empirical evidence is scarce, the link is widely accepted: by targeting their underlying financial motivation, asset confiscation contributes to discouraging these kinds of criminal activity. The logic gained particular ground when viewed alongside a relative failure of traditional criminal justice tools to reduce organised crime. The profits generated by this type of criminal activity - especially through drug trafficking - tend to be far too great for the prospect of criminal prosecution and/or conviction to act as an effective deterrent. Moreover, asset recovery is also assumed to have other positive societal impacts, including promoting the public's confidence in the justice system, enhancing redistributive justice for victims of crime and adding to state budgets.

Asset recovery became particularly important in the European Union (EU) ${ }^{1}$ where organised crime has been a long-standing problem in several Member States. Moreover, the building of the internal market, with its twin effects of abolishing internal frontiers and enabling the free circulation of goods, capital, services and persons, was perceived as facilitating the activities of such criminal groups. This not only reinforced the need for coordination and cooperation at EU level, but also raised the issue of the EU's own responsibility in the propagation - and hence the combatting - of cross-border crime. That responsibility was further emphasised by the introduction of the Area of Freedom, Security and Justice (AFSJ) by the Treaty of Amsterdam, which gave substance to the link between the EU's aims on the economic plane and questions of security and justice. As a result, asset confiscation became central not only to the fight against organised crime across Europe and the pursuit of broader social objectives, but also to the EU's singular aspiration of creating an AFSJ. This led to the adoption of several measures designed to improve asset recovery and confiscation across the EU Member States, with the most recent instruments having entered into force in $2014 .^{2}$

However, the EU's intervention does not appear to have resulted in any significant increase in the amount of confiscated assets. While there is no comprehensive statistics on the number of domestic or cross-border confiscation orders or the exact

\footnotetext{
*The authors would like to express their gratitude to colleagues at RAND Europe, namely Barry Irving and James Forsaith; and researchers at the ANTICORRP research project, namely Salvatore Sberna and Pedro Gomes Pereira. In addition, the authors would also like to thank the anonymous reviewer for providing constructive and critical comments.

${ }^{1}$ The 1997 Action Plan to Combat Organised Crime emphasise the link between effective asset recovery and the combatting of organised crime.

${ }^{2}$ See in particular Directive 2014/42/EU of the European Parliament and of the Council of 3 April 2014 on the freezing and confiscation of instrumentalities and proceeds of crime in the EU [2014] OJ L138/114 (hereinafter the 'new Directive').
} 
value of confiscated assets, interviews with practitioners and selected national statistics suggested little to no improvement over time. At one extreme, the Austrian extended confiscation regime introduced in 2002 has virtually never been used. At the other extreme, the low rate and limited success of confiscation orders remain key concerns for practitioners even in forerunner countries such as Italy, the Netherlands, or the UK, where the value of confiscated assets has reached the order of 100 million EUR per year. Likewise, there is no evidence of significant cross-border use of the EU instruments, calling into the question the added value of the EU's intervention.

In order to shed light on the lack of progress in a crucial area of criminal law and policy, this article seeks to identify the main legal and institutional factors that impede the effectiveness of the EU's asset confiscation regime and thus explain why coordinated action at EU level has not significantly improved the recovery of criminal proceeds across Europe. In doing so, it will also evaluate the extent to which the new Directive on asset confiscation and the Treaty of Lisbon are likely to make a difference. Moreover, given a large number of EU instruments designed to build the $\mathrm{AFSJ}^{3}$ are also characterised by a degree of approximation of national legislation and implementation of the principle of mutual recognition - the two pillars of the EU's asset confiscation regime - our findings may also be relevant to other areas of criminal justice where the EU's action has not proven particularly effective. This is particularly likely given that some of the legal impediments to effective action in this field are linked to broader systemic features of the EU's institutional and constitutional arrangements rather than to considerations that are specific to asset confiscation. As such, identifying the impediments to effective EU action in this field is not only important to improving asset recovery work across Europe but may also contribute to debates about the EU's broader strategy in matters pertaining to the AFSJ.

To that end, section 1 starts by outlining the EU's legal framework in the area of asset confiscation, as well as the problems that have arisen in practice. Drawing on a legal and institutional mapping of the field across Europe, ${ }^{4}$ the article then moves on to identifying the causes of the low recovery rates. Section 2 focuses on the legal impediments, showing how the relevant EU rules still present a number of deficiencies. Second 3 turns to the transposition stage, exploring why the transposition of the relevant EU legal tools has remained rather poor across Member States. Section 4 then looks at the institutional barriers that prevent the effective use

\footnotetext{
${ }^{3}$ See also T. Obokata, 'Key EU Principles to Combat Transnational Organised Crime' (2011) 48 Common Market Law Review 801.

${ }^{4}$ The legal and institutional mapping we draw upon provided the background work for a report commissioned as part of the Commission's impact assessment that led to the adoption of the new Directive. See F. James, B. Irving, E. Nanopoulos and M. Fazekas, 'Study for an Impact Assessment on a Proposal for a New Legal Framework on the Confiscation and Recovery of Criminal Assets', (2012) RAND Europe, Cambridge, hereinafter the 'RAND report'.
} 
of these instruments in practice. Finally, section 5 offers some suggestions as to the possible way forward.

\section{Asset Confiscation in the $\mathbf{E U}$}

\subsection{Legal Framework}

Despite the fact that the EU's powers in the field of criminal law and justice have been historically rather limited, the EU has been quite active in the field of asset confiscation. The EU's action in the field has comprised three main elements, although only the first two are considered in greater detail in this contribution: a degree of harmonisation of relevant domestic laws and procedures, provisions on the mutual recognition and enforcement of confiscation and freezing orders and some institutional measures.

\subsubsection{Approximation of Domestic Laws}

Efforts to approximate the laws of the Member States in this area date back to Joint Action 98/699/JHA, ${ }^{5}$ which required the adoption of measures enabling the confiscation of the instrumentalities and proceeds of crime for which a criminal conviction has been obtained ('ordinary confiscation') and/or of assets of equivalent value ('value confiscation'). In line with the general trend prevalent in the aftermath of the Treaty of Amsterdam - the so-called 'second wave' of EU criminal law ${ }^{6}$ - this Joint Action was replaced by Framework Decision 2001/500/JHA, ${ }^{7}$ which enshrined the relevant provisions in a more prescriptive legal form. This reform had little substantive impact, however, as the relevant rules still consisted of broadly defined obligations and were primarily intended to promote the implementation of relevant international instruments rather than to give effect to a distinct EU agenda or policy in this area.

The first steps towards a more comprehensive EU regime started to emerge with the adoption of Framework Decision 2005/2012/JHA on the harmonisation of confiscation laws. This instrument required the adoption of measures enabling the confiscation of the proceeds and instrumentalities for 'all criminal offences punishable by deprivation of liberty for more than one year' and introduced provisions on extended confiscation, a technique designed to enable the confiscation of assets that cannot be linked to the specific offence for which a person has been

\footnotetext{
${ }^{5}$ Joint Action 98/699/JHA [1998] OJ L333/1.

${ }^{6}$ V. Mitsilegas, 'The Third Wave of Third Pillar Law: Which Direction for EU Criminal Justice' (2009) 34 European Law Review 530.

${ }^{7}$ Framework Decision 2001/500/JHA on money laundering, the identification, tracing, freezing, seizing and confiscation of instrumentalities and the proceeds of crime [2001] OJ L182/1.
} 
convicted but nonetheless derive from that person's criminal activities. However, partly because of differences in national rules of criminal procedure, including as regards the standard and burden of proof, and partly because of human rights concerns about the use of presumptions to establish the criminal origin of the assets, ${ }^{8}$ the Framework Decision did not establish a uniform regime but left Member States a choice between three different options. Moreover, extended confiscation was only required for a list of serious offences and only when these were committed within the framework of a criminal organisation.

These instruments will be partially replaced by the new Directive, ${ }^{9}$ which entered into force in April 2014 and which Member States have until October 2016 to implement. ${ }^{10}$ The new Directive partly consolidates the existing rules. It requires ordinary and value confiscation ${ }^{11}$ for a number of serious offences listed in Article 3, such as corruption and organised crime, including where the conviction results from proceedings in absentia. It clarifies that indirect proceeds include proceeds obtained by reinvestment - a question that was left open by Framework Decision 2005/2012/JHA. It also unifies the regime for extended confiscation, which is now required for all situations where a court is satisfied that the property in question is derived from criminal conduct ${ }^{12}$ on the basis of the circumstances of the case, such as when there exist discrepancies between the person's income and the total value of their assets. Extended confiscation is no longer limited to offences committed in the framework of a criminal organisation, but it only applies to crimes that are liable to give rise to economic benefit, thus maintaining a focus on organised crime. Moreover, the regime is still singled out in terms of its scope of application: whilst it is available unconditionally for a number of cases described in Article 5 of the new Directive, ${ }^{13}$ it only applies to the offences listed in Article 3 if they carry a custodial sentence of a maximum of at least four years.

In addition, the new Directive brings a number of novelties in this field, even though it is a rather watered-down version when compared to the original proposal put forward by the European Commission. The first set of changes concerns the scope of asset confiscation powers. The Directive introduces a limited form of non-conviction

\footnotetext{
${ }^{8}$ Although extended confiscation is not considered to be a criminal charge, the presumption of innocence still applies and has for example been held to prevent the confiscation of assets for crimes of which the person has been specifically acquitted. See Geerings v Netherlands (2007) 46 EHRR 49.

${ }^{9} \mathrm{JA}$ is completely replaced whilst only some provisions of the two Framework Decisions are. See Art 14 of the new Directive.

${ }^{10}$ The original deadline for the implementation of the new Directive was October 2015, but was subsequently extended to October 2016. See Corrigendum to Directive 2014/42/EU [2014] OJ L138/114.

${ }^{11}$ Framework Decision 2001/500/JHA seemed to only require it where the assets could not be seized. See arts 2 and 3 Framework Decision 2001/500/JHA.

${ }^{12}$ Art 5 of new Dir.

${ }^{13}$ These are broadly speaking connected to corruption, participation in a criminal organisation, child pornography and illegal system and data interference. See art 5(2) intent (a) to (d) of the new Dir.
} 
based confiscation ${ }^{14}$ where a conviction is not possible because the accused is ill or has absconded but the proceedings have already been initiated and would have led to a criminal conviction if he or she had been able to stand trial. This form of criminal non-conviction based confiscation differs from the civil non-conviction based regimes - also known as civil forfeiture - introduced in some Member States, ${ }^{15}$ as the latter tend to target directly the property (rather than a defendant) and dispense with the requirement that criminal conduct be established to a criminal standard of proof, relying instead on civil rules of evidence and procedure. Like extended confiscation, moreover, the EU's criminal non-conviction based confiscation is limited to offences that are liable to result in economic benefit. The new Directive also for the first time explicitly requires the confiscation of assets in the possession of third parties ${ }^{16}$ when they 'knew or ought to have known that the purpose of the transfer of acquisition was to avoid confiscation', which must be established by 'concrete facts and circumstances', such as when the relevant property was obtained 'free of charge or in exchange for an amount significantly lower than the market value'. The term third party specifically excludes bona fide persons, ${ }^{17}$ whose rights remain unaffected.

The second set of novelties relate to the stages of the asset recovery process that are being regulated at EU level. The original instruments primarily focused on the confiscation stage i.e. the circumstances under which courts can order confiscation. Council Decision 2007/845/JHA, which requires Member States to establish asset recovery offices ${ }^{18}$ to facilitate the tracing and identification of cross-border criminal assets, including by exchanging information and best practices, touched upon aspects of the investigation stage. But there were no attempts to lay down common minimum standards to ensure that assets are preserved pending the completion of the criminal proceedings and the adoption of a confiscation order (the preservation stage) or that such orders are enforced in practice (the enforcement stage).

By contrast, the Directive requires the adoption of measures enabling the freezing of assets and covering both prohibitions on use and the temporary seizure of property, as well as measures aimed at ensuring the management of frozen property. Freezing orders can be issued by any 'competent authority' in all cases where the property might be liable to subsequent confiscation, including from third parties, and shall include the taking of 'urgent action'. Moreover, the Directive specifies that such orders must remain in force for as long as necessary but that the property must be

\footnotetext{
${ }^{14}$ For a critical analysis see M. Simonato, 'Directive 2014/42/EU and Non-Conviction Based Confiscation: A Step Forward on Asset Recovery?’ (2014) 6 New Journal of European Criminal Law 213.

${ }^{15}$ E.g. The UK Proceeds of Crime Act 2002.

${ }^{16}$ Under art 3(3) of Framework Decision 2005/2012/JHA, Member States were simply encouraged to enable the confiscation of property acquired by the closest relations of the accused or transferred to a legal person over which the accused has a controlling influence.

${ }^{17}$ Art 6(2) of the new Dir.

${ }^{18}$ This complements the pre-existing CARIN practitioner network.
} 
immediately returned if no confiscation order is adopted. ${ }^{19}$ Management measures, on the other hand, are left entirely at the discretion of Member States, although these should at least include the possibility to sale or transfer the property. As regards the enforcement stage, the new Directive includes an express obligation for Member States to ensure the execution of confiscation orders and to enable the detection and tracing of property even after the conviction or the criminal non-conviction based proceedings. ${ }^{20}$ This latter addition is probably a result of the fact that, in many Member States, the possibility to confiscate criminal assets ends when the proceedings are finalised, which not only encourages criminals to provisionally conceal their assets but also tends to rush the financial investigation. However, in line with the multi-layered nature of the EU's system of governance, which largely leaves the enforcement of EU law to domestic authorities, the relevant provision does not otherwise prescribe how or by whom such enforcement should take place.

Finally, the new Directive introduces a number of procedural safeguards in this field, beyond the requirement to interpret and apply relevant EU law in line with fundamental rights, including the EU Charter of Fundamental Rights. Thus, provided this does not jeopardise the conduct of the investigation, freezing and confiscation orders must, together with the reasons for their adoption, be communicated to the affected person as soon as possible after their execution ${ }^{21}$ and be open to challenge before a court. ${ }^{22}$ Moreover, Member States shall ensure that third parties are entitled to claim ownership of the property and that victim can seek compensation, although it is not clear whether the latter claim is contingent upon domestic law providing for such a cause of action.

\subsubsection{Mutual Recognition}

The second set of EU instruments - Framework Decision 2003/577/JHA ${ }^{23}$ on the mutual recognition of freezing orders and Framework Decision 2006/783/JHA ${ }^{24}$ on the mutual recognition of confiscation orders - are aimed at facilitating the recovery of assets in cross-border cases. They are based on the principle of mutual recognition, which was first introduced by the EU judiciary in the context of the internal market ${ }^{25}$ as a means to enable the free circulation of goods and persons. Although its

\footnotetext{
${ }^{19}$ Art 8(3) and (5) of the new Dir.

${ }^{20}$ Art 9 of the new Dir.

${ }^{21}$ ibid, art 8(2).

22 ibid, art 8(4).

${ }^{23}$ Framework Decision 2003/577/JHA of 22 July 2003 on the execution in the European Union of orders freezing property or evidence [2003] OJ L196/45.

${ }^{24}$ Framework Decision 2006/783/JHA of 6 October 2006 on the application of the principle of mutual recognition to confiscation orders [2006] OJ L328/59.

${ }^{25}$ Case 120/78 Cassis de Dijon [1979] ECR 649.
} 
transposition into the criminal law field is far from uncontroversial, ${ }^{26}$ it has come to be described as the cornerstone of judicial cooperation in civil and criminal matters ${ }^{27}$ and rests upon the alleged mutual trust in the criminal justice systems of the Member States corroborated by a presumption of compliance with fundamental rights across the EU. As such, the two instruments require freezing and confiscation orders to be recognised and enforced in other Member States. Practically speaking, the orders are transmitted alongside a 'certificate' to the competent authorities in the executing State, which must recognise them without further formalities and to forthwith take the measures necessary for execution. ${ }^{28}$ Mutual recognition is automatic for a list of offences ${ }^{29}$ punishable by at least three years of imprisonment in the issuing State, but dual criminality is still necessary in other cases i.e. recognition can be refused if the crime to which the freezing or confiscation order relates is not a criminal offence under the laws of the executing State. In addition, the Framework Decisions still allow (optional grounds) - and even require (mandatory grounds) - competent authorities to refuse or postpone recognition or enforcement in certain situations. ${ }^{30}$

The two instruments are unaffected by the new Directive, but the Framework Decision on the mutual recognition of freezing orders will be absorbed into Directive 2014/41/EU on the European Investigation Order, which extends the mutual recognition principle to almost all investigation measures involving the transfer of evidence and adds to the general move towards the formal integration of the old third pillar into the Community pillar, including through the conversion of Framework Decisions into EU Directives. The original proposal purported to abolish the dual criminality, territoriality and non bis in idem principles, but these were re-introduced into the final version. Criticism over the principle of mutual trust and a set of adverse judgments by the European Court of Human Rights (ECtHR) ${ }^{31}$ - and subsequently the Court of Justice of the EU (CJEU) ${ }^{32}$ - over its practical operation in the context of the European common asylum system also led to a provision allowing Member States for the first time to refuse execution where there are substantial grounds to believe that this would be incompatible with fundamental rights.

\subsection{Effects in Practice}

\footnotetext{
${ }^{26}$ E.g. A. Hinarejos, 'Integration in Criminal Matters and the Role of the Court of Justice' (2011) 36 European Law Review 420.

${ }^{27}$ Tampere European Council, 1999.

${ }^{28}$ See Art 5 of Framework Decision 2003/577/JHA and Art 7 of Framework Decision 2006/783/JHA. Framework Decision 2003/577/JHA explicitly states that freezing orders are to be executed in the same way as for a freezing order made by an authority of the executing state; Framework Decision 2006/783/JHA does not contain an equivalent statement for confiscation orders.

${ }^{29}$ The list includes, but goes far beyond, the offences covered by Art 3 of the New Directive. See Art 3 of Framework Decision 2003/577/JHA and Art 6 Framework Decision 2006/783/JHA.

${ }^{30}$ Art 7 and 8 of Framework Decision 2003/577/JHA and Art 8 of Framework Decision 2006/783/JHA.

${ }^{31}$ M.S.S. $v$ Belgium and Greece (2011) 53 EHRR 2.

32 Joined Cases C-411/10 and C-493/10 NS, judgment of 21 December 2011, nyr.
} 
Despite this plethora of legal instruments and the corresponding reforms that they have thus far prompted at domestic level, the amount of confiscated assets in the EU remains marginal. As we mentioned, the Austrian extended confiscation regime introduced in 2002 has virtually never been used, while in Hungary, authorities only confiscate assets in cash form, which is evidenced by a mere 598 forfeiture procedures out of 86705 convictions with nearly half relating to economic and property crimes. Admittedly, in countries with a longer history and practice in asset confiscation such as Italy, the Netherlands, or the UK, recovery rates suggest that utilisation is higher. In Italy, for example, the value of confiscated assets reached around 100 million EUR per year in 2007-2009, while it went well above 100 million GBP per annum in the UK. But according to interviewed practitioners, the potential for improving utilisation rates remains high even in those countries. Moreover, those practitioners pointed out that mutual recognition instruments were rarely or never used. As such, the problem of utilisation applies with equal force in cross-border cases.

Admittedly, there are significant methodological difficulties in measuring the 'gap' in confiscated assets, that is the gap between the amount of confiscated assets compared to the optimal amount of confiscated assets, and hence the exact extent of the problem. This is because it is virtually impossible to identify and determine the total amount of criminal assets i.e. including those connected to crimes whose perpetrators have not been identified or formally charged. Moreover, there is a general paucity of data available on even the most essential aspects of asset confiscation work across the 28 Member States, including the costs incurred by public administrations and the total amount of confiscated assets. The new Directive is likely to improve those figures as it includes a number of obligations on the keeping of statistical data in both domestic and cross-border cases. But it will take some time even after transposition before these obligations begin to have a meaningful impact. Under the present conditions, the most widely used indicator of success has been the ratio of confiscated to identified assets. However, it is too narrowly focused on the officially recorded aspects of the recovery process and fails to take into account the fact that a large proportion of criminal assets are simply not identified.

Yet, numerical data from a number of selected examples ${ }^{33}$ in relation to which sufficient statistical information was publicly available as well as the interviews we carried out across Europe ${ }^{34}$ all confirmed the basic difficulty of increasing the rate of recovered assets, including in countries most heavily investing into asset recovery, and already showed a number of important utilisation challenges. As such, based on a legal and institutional mapping of the field across EU Member States, the next three

\footnotetext{
${ }^{33}$ Countries with more extensive statistics and research are Bulgaria, France, Hungary, Ireland, Romania, and the UK.

${ }^{34}$ See Rand report, above $n$ 4, annexe A.
} 
sections explore some of the barriers to the effectiveness of the EU's action in the field of asset confiscation.

\section{Legal Barriers}

The first set of barriers to the effectiveness of asset confiscation arises from deficiencies in the EU legal framework itself. While the two Directives will bring several improvements to the field, a number of considerations still cast doubt over the extent to which the relevant rules provide Member States with the necessary legal tools to ensure effective recovery at domestic level (2.1) or noticeably advance cooperation in cross-border cases (2.2).

\subsection{Barriers to Effective Confiscation Laws}

One of the purposes of approximating national legislations is to ensure that all Member States possess the legal tools necessary for effective recovery and the legal mapping indeed suggested that the EU could play an important role in this area as not all Member States have in place comprehensive asset confiscation regimes. Yet, the EU regime itself contains a number of important gaps. There may of course be questions as to whether the EU should require Member States to introduce civil nonconviction based regimes, as these raise a number of human rights issues ${ }^{35}$ and have been controversial in some of the Member States where they have been introduced. But it is less clear why the non-conviction criminal regime should not for example extend to instances where the defendant enjoys immunity from trial, which may be particularly crucial in countries where public officials are themselves enmeshed (e.g. through corruption) in criminal networks.

Even when there is no formal gap, some of the rules are too vague or leave the Member States' too much discretion to ensure that effective rules will be put into place at domestic level. The point about discretion is particularly pronounced as regards the new provisions on the management of frozen assets, the enforcement of confiscation orders and the social re-use of confiscated assets, ${ }^{36}$ all of which merely impose loosely defined targets for the Member States to achieve rather than concrete obligations. Yet, these aspects of the recovery process are crucial to meeting the social (rather than deterrence) objectives of asset confiscation and could have a strong role to play in incentivising asset confiscation work. On the other hand, the point about definitional ambiguities can be illustrated with reference to the term 'third party' in the new Directive. Although the preamble specifies that third party

\footnotetext{
${ }^{35}$ For a discussion see K. Mahmutaj, 'Cash Forfeiture following Acquittal: An "Affront to Public Perception” or a Breach of a Fundamental Human Right?’, (2009) 11 Criminal Law Review 783.

${ }^{36}$ S. Montaldo, 'Directive 2014/42/EU and Social Reuse of Confiscated Assets in the EU: Advancing a Culture of Legality' (2015) 6 New Journal of European Criminal Law 195.
} 
confiscation should extend to legal persons, ${ }^{37}$ it is not clear how the requirement of knowledge will, in those cases, be satisfied and hence whether this falls within the mandatory scenarios in relation to which Member States must introduce appropriate legislation. If not, that would be a significant omission as corporate bodies and other legal persons are often used to conceal criminal proceeds.

In some instances, the EU regime not only lacks clarity but also imposes conflicting obligations upon Member States. For example, Article 2 of Framework Decision 2005/2012/JHA, which in principle remains unaffected by the new Directive even though they cover substantively the same ground, requires ordinary confiscation in relation to all 'criminal offences punishable by deprivation of liberty for more than one year', whilst the Directive only does so for a number of listed offences. This can be explained by the fact that Article 83(1) TFEU, on which the new Directive is partly based, only allows the adoption of minimum rules as regards the definition of criminal offences and sanctions 'in areas of particularly serious crime with a crossborder dimension', which are expressly listed in that provision. ${ }^{38}$ But it does create inconsistent obligations in the particular area of overlap i.e. ordinary and value confiscation. Incidentally, it is unlikely that Framework Decision 2005/2012/JHA is compatible with Articles 83(1) and Article 82(2) TFEU - the other legal basis for the new Directive, creating further confusion in the legal landscape. The conflict between these two instruments also signals a deeper ambivalence about the EU's approach to asset confiscation. Indeed, it is not clear whether ordinary confiscation is seen as a punitive tool, in which case it could potentially apply to all criminal offences, or whether it is designed to deter particularly serious forms of crime, in which case its scope of application ought to be limited. The question is not merely theoretical as our legal mapping suggested that differences in domestic laws can sometimes be explained by differences in the conceptualisation of the nature and purpose of asset confiscation.

In addition, it is not clear that the EU measures necessarily address the kind of legal issues that appear to be crucial to an effective asset recovery regime. Often, the issue is not so much whether a particular Member State has asset confiscation laws in place, but the precise modus operandi of the regime, including as determined by that State's broader principles of criminal law and procedure. Thus, for example, low rates of confiscation orders often result from the fact that domestic law prescribes a high standard of proof as to whether particular assets are proceeds of crime, which is difficult to meet. ${ }^{39}$

\footnotetext{
${ }^{37}$ ibid, rec 24.

${ }^{38}$ The current list covers terrorism, trafficking in human beings and sexual exploitation of women and children, illicit drug trafficking, illicit arms trafficking, money laundering, corruption, counterfeiting of means of payment, computer crime and organised crime. All the offences to which the new Directive applies can be linked to one of those crimes. See article 3 of the new Directive.

39 J. Benseler, 'Forfeiture Legislation in Germany: Legal Basis and Prosecution Practice' (1997) 5 European Journal of Crime, Criminal Law and Criminal Justice 203, 207.
} 
In fact, there are doubts as to whether a uniform approach to asset confiscation is necessarily the most effective way to enhance the effectiveness of domestic confiscation laws. Our legal mapping suggested that different States might require different legal tools depending on the particular form and scale of organised criminal activity in their territory and/or the broader characteristics of their criminal justice system. Thus, extended confiscation may be redundant or disproportionate in countries like France, which criminalises the unjustified ownership of assets of particular categories of people, or in countries like Spain where money laundering is defined without reference to a specific predicate offence. On the other hand, civil nonconviction based confiscation might be needed in countries with stricter criminal law standards, which prevent convictions. Likewise, countries with particularly entrenched forms and high levels of organised crime may need more far-reaching tools than countries were criminality is relatively low. In fact, the threat posed by mafia-induced crime in Italy was crucial to the ECtHR's judgment that Italy's regime, which combines elements of both non-conviction based and extended confiscation and is thus amongst the most far-reaching in Europe, did not constitute a disproportionate interference with the right to property. ${ }^{40}$ Moreover, there may be a greater need for effective preventative tools in large financial and/or banking centres, such as Luxembourg, which may be more prone to financial crime.

\subsection{Barriers to Cross-Border Cooperation}

There are also a number of important legal barriers to cross-border cooperation, some of which directly result from the instruments on mutual recognition, whilst others relate to the EU's broader legal strategy in fostering cross-border cooperation.

From a purely formal perspective, it is unclear whether the particular form mutual recognition takes is conducive to facilitating and streamlining cooperation between judicial authorities. Many practitioners reported that the mutual recognition certificates were rather complicated and lengthy, adding to, rather than diminishing, the bureaucratic burden on the State apparatus. In fact, practitioners reported that they usually prefer to have resort to the older and more familiar agreements on mutual legal assistance, ${ }^{41}$ which continue to apply alongside the Framework Decisions on mutual recognition. This was particularly the case where requests for assistance not only concern the enforcement of a freezing or confiscation order but also other investigative or enforcement action (e.g. the search or transfer of evidence), in which case a mutual legal assistance request will have to be made anyway. The European

\footnotetext{
${ }^{40}$ Arcuri v Italy (2001) ECtHR 4 July 2001.

${ }^{41}$ Some are general in nature, whilst others relate more specifically to asset confiscation. Examples of the former include Council of Europe Convention on mutual assistance in criminal matters 1959 and Council Act of 29 May 2000 establishing the Convention on mutual assistance in criminal matters between the Member States of the European Union [2000] OJ C197/24. Examples of the latters include Council of Europe 1990 and 2005 Conventions and UN Palermo Convention.
} 
Investigation Order might slightly improve the situation, as it provides for a single physical form to be filled for all investigation measures and displaces the application of mutual legal assistance instruments, but it does not otherwise fundamentally alter the EU's approach to cross-border cooperation.

In addition, although the possibility to block recognition is crucial to the operation of the principle of mutual recognition, some of the grounds for refusal seem to leave unnecessary discretion to domestic judicial authorities and/or lack justification. For example, it is not clear whether the possibility to refuse execution if it conflicts with third-party rights would apply to instances where a confiscation order would interfere with the rights of legal entities set up by the convicted person to hide his or her illicit gains, ${ }^{42}$ in which case it would be relatively easy for the person to take advantage of the legal loopholes created by the free movement of capital or the freedom of establishment.

Thirdly, the mutual recognition instruments do not cover all the types of freezing or confiscation orders that can be adopted at domestic level, thus often preventing recognition and enforcement. For example, while Framework Decision 2003/577/JHA explicitly applies to extended confiscation orders, no similar provision exists in Framework Decision 2003/577/JHA, which is limited to ordinary confiscation. Thus, a freezing order issued with a view to confiscating proceeds that are not connected to the specific crime for which the person is being prosecuted cannot be automatically enforced in another Member State. While this may be explained by the fact that Framework Decision 2003/577/JHA predates Framework Decision 2005/212/JHA, the omission is liable to impair the effectiveness of extended confiscation regimes, as the whole purpose of freezing regimes is to prevent assets from being disposed of. The problem is not expressly addressed in the European Investigation Order and will worsen after the deadline for the transposition of the new Directive will pass, given that none of the mutual recognition instruments apply to criminal non-conviction based confiscation or third party confiscation.

In a similar vein, some types of confiscation orders need to be enforced through other channels, adding to the complexity of the regime and the difficulties facing domestic authorities when seeking to recover assets abroad. ${ }^{43}$ Thus, confiscation orders adopted for the purpose of compensating the victim rather than a criminal penalty must be enforced through Framework Decision 2005/214/JHA on the mutual recognition of financial penalties rather than Framework Decision 2003/577/JHA. Similarly, civil non-conviction based confiscation orders must go through the procedure laid down in the Brussels I Regulation. ${ }^{44}$ As of January 2015, the recast Brussels I Regulation

\footnotetext{
${ }^{42}$ Art 8(2)(d) Framework Decision 2006/783/JHA.

${ }^{43}$ For a fuller discussion see Rand report, above n 4, 43-44.

${ }^{44}$ Council Regulation (EC) 44/2001 of 22 December 2000 on jurisdiction and the recognition and enforcement of judgments in civil and commercial matters [2001] OJ L12/1 now repealed by
} 
abolished the exequatur procedure ${ }^{45}$ and will thus facilitate the enforcement of such orders, but it is still possible for the executing Member State to refuse recognition or enforcement if it is manifestly contrary to public policy. ${ }^{46}$ Moreover, this route raises particular difficulties when civil courts in the executing Member State, such as in Spain, lack themselves jurisdiction under domestic law to issue civil non-conviction based orders. ${ }^{47}$ To bypass such difficulties, the UK has for example adopted a more practical approach, by providing Spain with the information necessary to allow it to obtain a criminal conviction and, hence, confiscation. But the problem of automatic enforcement remains. It also raises difficulties for countries like Finland, Sweden or Denmark where criminal courts can exercise civil jurisdiction to order compensation for the victim at the request of the prosecutor. This principle of 'adhesion', whereby a civil case is adhered to a criminal case, gives the victim a claim against the criminal, but given the cost and efforts involved in having recourse to the Brussels I procedure, these are rarely pursued. The upshot is that criminal assets remain unrecovered and victims remain uncompensated.

There are also problems with the EU's wider legal strategy for promoting crossborder cooperation. First, one of the implications of the analysis in section 1.1. is that EU law does not necessarily guarantee that differences in national legislations that tend to create difficulties in the recognition and enforcement of freezing or confiscation orders in cross-border cases are eliminated, as the open-ended and vague nature of some of the obligations inevitably results in discrepancies between domestic laws. The risk of divergences is particularly pronounced given that compliance with the principles of legality or legal certainty requires States to add detail to the relevant EU law provisions if they want their asset confiscation laws to meet the conditions of precision and foreseeability inherent in these two principles. ${ }^{48}$ More importantly, two Member States - Denmark and the UK - have not 'opted-in' to the new Directive and hence will be altogether subject to different rules. As such, the premise of uniformity allegedly necessary to effective cross-border cooperation is unlikely to fully materialise.

Last but not least, there are issues with how the EU goes about constructing the mutual trust that is supposedly underpinning the principle of mutual recognition. ${ }^{49}$

Regulation (EU) No 1215/2012 of the European Parliament and of the Council of 12 December 2012 on jurisdiction and the recognition and enforcement of judgments in civil and commercial matters [2012] OJ L351/1.

${ }^{45}$ Regulation (EU) No 1215/2012 ibid, art 58.

${ }^{46}$ Regulation (EU) No 1215/2012 ibid, art 45.

${ }^{47}$ In Spain, for example, only criminal courts can order freezing.

${ }^{48}$ For an example from another field see F. Calderoni, 'A Definition that Could Not Work: the EU Framework Decision on the Fight Against Organised Crime’ (2008) 16 European Journal of Crime, Criminal Law and Criminal Justice 265.

${ }^{49}$ E.g. V. Mitsilegas, 'The Limits of Mutual Trust in Europe’s Area of Freedom, Security and Justice: From Automatic Inter-State Cooperation to the Slow Emergence of the Individual' (2012) 31 Yearbook of European Law 319. 
The harmonisation of asset confiscation laws may well foster confidence between domestic authorities by ensuring that freezing and confiscation order are adopted under broadly speaking similar procedures and conditions. But the over-emphasis on confiscation tools has, like in other fields, resulted in an 'bias towards law enforcement ${ }^{50}$ at the expense of other considerations, such as the protection of human rights or the pursuance of social objectives, which ultimately diminishes rather than enhances trust. The insertion of procedural safeguards into the new Directive, the ability to exercise a limited form of human rights review under the European Investigation Order, as well as broader initiatives to harmonise procedural aspects of criminal laws ${ }^{51}$ all constitutes attempts to remedy this imbalance. At the same time, however, they signal a rather limited approach to the concept and pursuit of mutual trust as centred around compatibility with individual rights rather than the building of a more cohesive and collective form of trust. The provisions on social-reuse could have been an opportunity through which to pursue such goals, but as we have seen, there are too 'thin' to make any significant difference in practice.

\section{Transposition Problems}

The second type of barriers to the effectiveness of the EU's regime arises from the lack of proper and/or timely transposition of the relevant rules into domestic laws. None of the legal instruments adopted in this field are directly applicable in the Member States and hence require transposition before they can take effect at domestic level. Yet, back in 2010, a number of Member States had still taken no steps at all to give effect to the relevant instruments ${ }^{52}$ and even when they did, transposition fell short of the requirements lay down in the corresponding EU instruments. As regards Framework Decision 2005/212/JHA, the problem was particularly pronounced in the implementation of the provisions on extended confiscation. Three Member States had not introduced such a regime into their domestic laws; ${ }^{53}$ others put in place stricter regimes, requiring for example proof that the accused intended to benefit from the crime; ${ }^{54}$ and others narrowed the scope of application of the regime, limiting extended confiscation to money laundering ${ }^{55}$ or a number of very serious offences punishable by a minimum period of imprisonment ranging from 3 years to life sentences or to cases where they are significant proceeds. ${ }^{56}$ Implementation was equally

\footnotetext{
${ }^{50}$ W. Wolfgang, 'Negative and Positive Integration in EU Criminal Law Co-operation' (2011) 15 European Integration online Papers available at: http://eiop.or.at/eiop/pdf/2011-003.pdf.

${ }^{51}$ E.g. Council Framework Decision 2009/299/JHA of 26 February 2009 amending Framework Decisions 2002/584/JHA, 2005/214/JHA, 2006/783/JHA, 2008/909/JHA and 2008/947/JHA, thereby enhancing the procedural rights of persons and fostering the application of the principle of mutual recognition to decisions rendered in the absence of the person concerned at the trial [2009] OJ L81/24.

${ }^{52}$ See table 3-2 in RAND report, above n 4, 48.

${ }^{53}$ Lithuania, Luxembourg and Slovenia.

${ }^{54}$ See Slovakia and Sweden.

${ }^{55}$ Greece.

${ }^{56}$ Poland sets a threshold of around 50000 EUR.
} 
unsatisfactory as regards the two Framework Decisions on mutual recognition. In some cases, Member States failed to transpose basic aspects of the framework, such as the definition of the terms 'freezing' or 'confiscation', which are autonomous concepts of EU law, into their domestic law, maintaining instead their own national definitions. In other cases, the relevant national laws played around with the rules lay down in the two Framework Decisions, ignoring or adding to some of its conditions. For example, some Member States did not include the requirement that freezing orders be recognised within 24 hours, ${ }^{57}$ whilst others added grounds for refusal/nonrecognition to the list, even though it is meant to be exhaustive. ${ }^{58}$

How can such transposition problems be explained? Some of the legal problems identified in the previous section inevitably have repercussions at the transposition stage: to the extent that EU obligations lack clarity or precision, their incorporation will continue to create difficulties in practice. Moreover, the EU's broader institutional and constitutional arrangements have not been particularly conducive to increasing transposition levels. Before the Treaty of Lisbon, no proceedings could be brought against Member States by the Commission for failure to transpose the Framework Decisions and domestic courts could only seek the input of the CJEU on the compatibility of their domestic laws with the EU legal framework on asset confiscation if their government had 'opted-in' to its jurisdiction. ${ }^{59}$ Private enforcement too was limited as direct effect was expressly precluded in the case of Framework Decisions. Moreover, although national courts were under an obligation to read national law in the light of the Framework Decisions, ${ }^{60}$ the interpretative obligation could not be used to impose or aggravate criminal liability, ${ }^{61}$ which may be a problem in countries where confiscation is seen as a criminal penalty. As such, there were few mechanisms in place to incentivise transposition and alternatives to ensure that, despite poor implementation, EU law can still take effect at domestic level. The situation is admittedly likely to improve. The CJEU was granted full jurisdiction in matters pertaining to the old third pillar in 2015. As such, it now has a say over the transposition of the Framework Decisions and can formally compel Member States to implement them. Moreover the new Directives will fall automatically within the scope of the CJEU's powers and their proper transposition will be further incentivised by the operation of the principles of (vertical) direct effect and State liability.

Yet, it is equally clear that such considerations alone are not sufficient to explain and hence to solve - deficiencies in transposition, which for example continue to arise in the context of EU Directives despite the existence of mechanisms to supervise their

\footnotetext{
${ }^{57}$ Hungary and Poland are two notable examples. Others, like Slovenia, have had to amend the constitutions following adverse judgments by their constitutional court.

${ }^{58}$ The most remarkable is the case of Hungary, which included non-recognition on the basis of a conflict with domestic law.

${ }^{59}$ See old Article 35 TEU.

${ }^{60}$ Case C-105/03 Criminal Proceedings against Maria Pupino [2005] ECR I-5285.

${ }^{61}$ Case C-268/06 Impact [2008] ECR I-2483, para.100.
} 
implementation. Moreover, our fieldwork suggested that a deeper problem might be at play, even though its exact nature still needs to be explored. Thus, in some Member States transposition issues arise from concerns to ensure compatibility with domestic constitutional law requirements. ${ }^{62}$ The provisions on extended confiscation were upheld in some countries such as the UK, but experts in Greece and Estonia doubted that they could survive constitutional challenge in their country. Similarly, Slovenia had to amend its constitution after its Supreme Court ruled that its non-conviction based confiscation was unconstitutional and Germany's 'asset penalty' was annulled by the German Constitutional Court. ${ }^{63}$ Moreover, the Romanian Constitution would seem to preclude the use of presumptions typical of extended confiscation regimes as Article 48(8) provides that legally acquired assets shall not be confiscated and that the licit character of acquired assets shall be presumed. In that regard, it is important to note that constitutional limits or impediments are not uniform across the EU and that even concepts such as the presumption of innocence or the right to property - which are common to most Member States - may be interpreted in very different ways.

Similarly, despite the exhaustive list of grounds for refusal in the Framework Decisions on mutual recognition, States are sometimes reluctant to completely strip their domestic courts of the ability to review foreign orders for their compatibility with human rights. The new jurisdiction of the CJEU, which will enable it to exercise some limited form of review on the compatibility of domestic laws falling within the scope of the EU's asset confiscation measures with EU fundamental rights, may slightly alleviate fears that the automatic recognition and recognition of a freezing or confiscation order may lead to a breach of fundamental rights. At the same time, the CJEU does not have jurisdiction over 'the validity or proportionality of operations carried out by the police or other law-enforcement services of a Member State or the exercise of the responsibilities incumbent upon Member States with regard to the maintenance of law and order and the safeguarding of internal security ${ }^{64}$ and thus over a number of quite sensitive aspects of asset confiscation, such as the gathering of information about the origin of the assets or the preventative seizure of property by police forces. Moreover, the EU standard of protection may also be lower than the one mandated by domestic legal requirements. Finally, it would seem that transposition issues sometimes arise because the relevant EU measures may prove to be ill-suited to the cultural or socio-economic conditions of a particular Member State. As such, there is a problem of 'translation' or 'adaptation' of the EU produced norm into the otherwise largely 'national' criminal justice system that is not readily detectable at the time the EU instrument is adopted but only arises once States attempt to put it into effect.

\footnotetext{
${ }^{62}$ For a full discussion see Rand report, above n 4, 45.

${ }^{63}$ Bundesverfassungsgericht, decision of 20 March 2002 (2002 NJW: 1779)

${ }^{64}$ Art 276 TFEU.
} 


\section{Institutional Barriers}

The final impediment to effective asset confiscation policies across Europe is the weak institutional capacities for putting asset confiscation instruments into practice. As is well known, the EU does not have its own independent enforcement apparatus but depends on its Member States for its application and execution. As such, the effectiveness of EU law very much depends on the extent to which Member States have the institutional capabilities on the ground.

In this particular context, successful recovery requires a complex set of institutions to work together at each stage of the recovery process i.e. the identification, preservation, confiscation, and enforcement stages. Each of the institutions fulfilling these four functions can suffer from deficiencies, which impede the effective utilisation of relevant legal powers and hence the success of the recovery process. On the basis of our institutional mapping which mapped the key institutional features that were lacking at national level based on an analysis of the available asset recovery statistics and a series of interviews with representatives of each of these institutions across Europe, ${ }^{65}$ we identified the following key problem areas.

Institutionally, there is first a significant 'cultural' problem. In most Member States, asset confiscation does not form part of the everyday practice and thinking of police officers, prosecutors or judges. This may be partly explained by the skills sets of each of these actors, which are rarely directly connected to asset confiscation (e.g. few judges' formal education include asset confiscation as a separate subject). But it also relates to their organisational culture, goals or priorities. For example, asset confiscation is often perceived to add to delays in the overall processing of pending cases, which is not looked upon particularly favourably (or even at all tolerated) in some countries. This has become even more problematic with the increase of judicial backlog and other pressures on domestic justice systems that have resulted from the budget cuts impacting them since 2010 .

A lack of 'motivational structures' capable of altering existing work patterns and priorities across the justice system represent the second major institutional barrier we identified. Devoting adequate time and resources for asset recovery necessarily requires greater investment on the part of those public bodies that take part in asset recovery work, be it investigative bodies, enforcement agencies or courts (e.g. hiring financial investigators, devoting scarce time). In most Member States, incentives for such investment, either positive or negative, are largely lacking. Asset confiscation usually comes on top of the traditional work of judges, investigators and other law enforcement officials without official recognition in performance evaluation, or

\footnotetext{
${ }^{65}$ See Rand report, above n 4, annexe A.
} 
organisational budgets (e.g. additional funds for the extra work entailed by asset confiscation activities).

Thirdly, there are difficulties in building new institutional frameworks - and particularly advanced financial investigation capabilities - that are necessary to support effective asset recovery, particularly now that post-financial crisis budget cuts reduced spending on crucial investigative tools in many Member States. A number of countries have created new specialised units or semi-independent bodies, which concentrate on the more complex and large-value cases. However, while it is relatively easy to train special magistrates to undertake such cases, the real challenge lies in linking up any such high capacity body to the rest of the justice system in such a way as to ensure that the whole system functions effectively. At the moment, the different institutions tend in contrast to operate in a rather disjointed manner.

Fourthly, within the EU, but at a global level too, organised crime is becoming increasingly internationalised and skilled in hiding illicit income and assets. Criminals have invested heavily into identifying and exploiting the loopholes of international legal regimes such as the existence of jurisdictions with high levels of financial secrecy or confidentiality or the lack of effective circulation of information between Member States. Yet, institutional fora for cooperation remain under-developed. International cooperation and data sharing is in particular hampered by the lack of language skills, inadequate knowledge of the most appropriate procedure (e.g. mutual recognition or mutual legal assistance), the administrative burden associated with the more complex international cases, and the lack of trust and willingness to cooperate among domestic bodies, ${ }^{66}$ despite an underlying assumption of confidence in each others' justice systems on the legal plane.

\section{Way Forward?}

\subsection{Methodology}

So what is the way forward? Methodologically, our mapping suggested that there is a need to better understand the legal and institutional barriers that impede asset recovery at domestic level. Whilst there is for example a sense that some Member States do not have the necessary legal tools in place for successful recovery or that cross-border cooperation is impeded by differences in national legislations, the exact nature or extent of the problem remains to be adequately pined down. In particular, any future legal or institutional mapping of the field would need to contextualise domestic rules and institutions by taking into account the broader legal, cultural and

\footnotetext{
${ }^{66}$ V. Van Tiggelen and L. Surano, 'Analysis of the Future of Mutual Recognition in Criminal Matters in the European Union, Institute for European Studies' (2008) Institute for European Studies, Université Libre de Bruxelles.
} 
socio-economic conditions prevalent in each Member State. To that end, the legal mapping should avoid recourse to universal legal categories, but should instead seek to evaluate domestic laws in the light of the particular form and scale of criminal activity in each of the Member State and the nature and purpose of confiscation within the relevant domestic legal system. Greater attention should also be paid to identifying the underlying causes for differences between Member States' laws and possible sources of distrust in their criminal legal systems. Moreover, far greater research should be put into understanding particular aspects and concepts of criminal procedures, such as standards of proofs, which tend to vary significantly between Member States. In fact, in some countries like France where emphasis is placed on the 'intime conviction du juge', it would be somewhat misleading to speak of 'standard of proof' in the traditional sense of the term. On the other hand, in order to more adequately understand institutional barriers, data on utilisation of asset confiscation tools should be collected on a disaggregated level (e.g. individual public bodies at different stages of the judicial process). In addition, resources committed to and costs associated with asset confiscation work should be measured separately so that targeted interventions to increase the necessary institutional capacities can be designed.

\subsection{Legal Solutions}

In terms of concrete legal solutions, given the new Directive and the European Investigation Order have just been adopted, the likelihood of a radical legislative change is small in the short term and there is an argument to the effect that these instruments should first be put into place prior to seriously re-thinking the area. Indeed, some of the officials we interviewed expressed the view that the mutual recognition measures should be allowed to 'settle' before considering reform as frequent legal changes make it even harder for practitioners to familiarise themselves with, and hence make greater us of, the EU instruments. Moreover, in addition to improving transposition, the institutional changes brought about by the Treaty of Lisbon as regards the public and private enforcement of the EU measures in this area might shed light on which barriers have the greatest impact on the effectiveness of asset confiscation work. In other words, if better transposition does not lift asset recovery numbers, it will suggest that the problem is either with the legal regime itself or with the institutional mechanisms in place to enforce it.

However, some smaller legal changes and developments could help enhance the effectiveness of the regime. In particular, the relationship between the different instruments could be clarified, and any conflicts abolished, by amending the relevant Framework Decisions. When solicited, the CJEU should also give clear guidance to domestic courts as to the interpretation of the relevant provisions of EU law, particularly when they place the onus on domestic courts to decide whether the 
relevant regime applies (e.g. whether the assets can be held to derive from criminal conduct in the case of extended confiscation).

Moreover, in preparation for future reforms, a wider debate should be initiated about the theoretical underpinnings of the EU's asset confiscation regime. ${ }^{67}$ Three things in particular would merit clarification. First, the EU should clarify the objective of asset confiscation in the EU. The rationale for acting at EU level seemed to have been the combatting of organised crime and the new Directive suggests indeed that confiscation should be reserved for the more serious forms of crime only, but the scope of the original Framework Decision is underpinned by a wider punitive objective. Second, the EU should clarify what the purpose of harmonisation is and whether this is indeed the best way to ensuring higher recovery rates. The Treaties themselves are rather obscure on this point. Article 82 TFEU makes a close link between the harmonisation of criminal laws and the facilitation of mutual recognition - indeed requires such a link for the harmonisation of certain listed aspects of criminal procedure - but it is not clear whether it applies to other areas, or what exactly it may require in practice. Article 83 TFEU, on the other hand, limits approximation of the definition of criminal offences and sanctions to serious crimes with a cross-border dimension, suggesting that the EU's intervention should be limited to particular forms of criminal activity whose scale and effects are such that it cannot be tackled by mobilising domestic repressive mechanisms alone. As a result, there is a striking opacity as to whether the approximation of domestic laws is designed to establish a minimum level playing field across the EU in particular areas, to eliminate differences in legal regimes that can be exploited by criminal organisations to further their aims, to facilitate mutual recognition, to build mutual trust among judicial and law enforcement bodies, to create a unified area of law or even just to facilitate free movement, a more economic objective. Often, these are all mentioned in tandem, but the lack of a focused and clearly articulated purpose makes the task of designing effective legal rules rather difficult. For example, vague principles may be appropriate if the aim is merely to ensure that Member States have some tools available at domestic level to confiscate criminal assets, but much less so if the objective is to abolish discrepancies or building trust. Finally, a serious debate should be had about the sort of measures or initiatives that could contribute to alleviating trust issues between Member States rather than focusing merely on strengthening the repressive arm of the State.

\subsection{Institutional Solutions}

\footnotetext{
${ }^{67}$ This echoes wider concerns about the theoretical implications of EU criminal law. E.g. M. Fletcher, B. Gillmore and R. Loof EU Criminal Law and Justice (Edward Elgar Publishing, 2008).
} 
However, the EU should not follow an exclusively legal strategy but also seek to contribute to the organisational and institutional difficulties faced by the Member States discussed in section 4. As regards first the need for better knowledge and information, the EU could for example support training provision for senior officials and those in charge of every day operations. One example of the transformative power of information provision and capacity development is the creation of the Identification of Criminal Assets Commission in France. This Commission contributed to greater knowledge of asset confiscation work (e.g. legal instruments, the role of specialised organisations etc) and provided expert support for investigators, which led to a noticeable culture change and achieved substantial results in terms of increasing the amount of confiscated assets. Training workshops are likely to be particularly indispensable for improving cross-border utilisation where differences in administrative regimes and languages provide further barriers.

The EU could also promote the establishment of adequate motivational structures capable of incentivising the utilisation of asset confiscation tools. Positive incentives could for example include the introduction of asset recovery-related standards into judges' performance evaluation, the granting of explicit external funds such as central government earmarked funds, or the creation of incentives directly out of the recovery work such as the possibility to retain a part of the profits from the confiscated assets. The success of the latter policy can for example be illustrated by the UK experience where asset recovery figures started to climb after the introduction of the Asset Recovery Incentivisation Scheme under which $50 \%$ of the revenue stream generated by confiscated assets is returned to the agencies who played a role in their recovery. The new Directive may itself contribute to creating such positive incentives a more robust legal regime may increase profitability margins, although its precise impact will depend on how such profits are re-distributed at the national level. Negative incentives may take the form of penalties/punishment for not contributing to asset recovery, as well as making the consideration of confiscating assets mandatory in criminal proceedings or at least limiting judicial discretion in utilising freezing and confiscation orders. Given the limited powers of the EU in the field of criminal procedure, however, these latter options may be more difficult to pursue at EU level.

The EU could also promote the creation of new organisational and institutional capacities that are best tailored to the particular needs of asset confiscation, as it has done by requiring the creation of asset recovery offices. The Criminal Assets Bureau in Ireland provides a good example of a specialised body armed with well-trained investigators that can achieve substantial results even when local level bodies are much less inclined and institutionally ready to incorporate asset confiscation work in their daily routines. Thus, the Criminal Assets Bureau recovers assets worth 10-20 
million EUR annually mainly relying on its own power to levy tax on previously undeclared income. ${ }^{68}$

\subsection{Limitations}

At the same time, there are necessary limits to the extent to which effective asset recovery, as a policy objective, can be pursued using the EU legal machinery. Even at domestic level, considerations of efficiency or crime deterrence have to be measured against broader ethical, legal and normative questions about the functioning and broader social purpose of the criminal justice system. Civil non-conviction based confiscation, for example, is criticised by civil liberties movements and tends to be controversial in capitalist economies centred on the protection of private property such that many Member States are averse to introducing that option into their domestic legal orders. But in the context of the EU, distinct issues arise as regard the justification for, and legitimacy of, EU intervention given that the EU has no general power to legislate in the field of criminal justice but is instead restrained by the principles of conferral, subsidiarity and proportionality, which have been held to be particularly important in the field of EU criminal law. ${ }^{69}$ In particular, despite some modest changes introduced by the Treaty of Lisbon, there continues to be a notable asymmetry between the EU's power to legislate in the field of substantive criminal law and its ability (and willingness) to regulate procedural aspects. As such, effectiveness issues that are traceable to particular features of domestic criminal procedures are difficult to address through the medium of the EU.

\section{Conclusion}

Particularly in the EU, there is a tendency to view the law and/or regulation as the primary vehicle through which to coordinate action and pursue particular objectives. The trend is amply illustrated in the field of asset confiscation, where the need to effectively combat organised crime provided the impetus for the introduction of common rules at the level of the EU and for procedures aimed at ensuring efficient cross-border cooperation between Member States. When the framework was shown to be largely ineffective in securing higher recovery rates, the answer was again sought on the legal plane, by amending parts of the relevant regime and expanding its scope to areas that were previously left unregulated. It is obviously too early to gauge the success of those amendments, as one will have to at least wait for the implementation deadlines of the new Directive and the European Investigation Order to pass before reaching more concrete conclusions.

\footnotetext{
${ }^{68}$ See annual reports of Ireland's Criminal Assets Bureau.

${ }^{69}$ E. Herlin-Karnell, 'EU Competence in Criminal Law after Lisbon' in A. Biondi, P. Eeckhout, and S. Ripley (eds) EU Law after Lisbon (OUP, 2012).
} 
Yet, the present article questioned the extent to which these are likely to mark an improvement in asset recovery work. Even as amended, the EU legal regime not only contains gaps, uncertainties and inconsistencies, but also fails to tackle the sort of issues that seem to impede effective recovery in practice i.e. there are questions as to whether it is suitable to achieving its stated objectives. The problem is aggravated by the fact that the EU regime lacks a clearly articulated purpose that would allow for a full rationalisation of the added value of EU intervention and the drawing of a regime that allows this potential to be fully realised. Moreover, the EU's over-reliance on formal legal solutions has come at the expense of other crucial institutional and utilisation questions, which cannot be tackled solely through legal reform. If anything, this structural bias for legal answers has been consolidated by the Treaty of Lisbon given that its main input towards improving the overall effectiveness of EU law in the AFSJ is through the tightening and institutionalisation of human rights protection, as well the introduction of more far-reaching enforcement and review mechanisms.

This approach is not particularly surprising if one has regard to the EU concept/principle of effectiveness, which has traditionally placed emphasis on ensuring the effectiveness of EU law qua law through various mechanisms such as the doctrines of direct effect or supremacy, rather than on the effectiveness of the underlying policies and objectives that EU law supposedly seeks to pursue. This may have worked in building the single market by removing obstacles to trade, as the mere enforcement of EU provisions on free movement was sufficient to achieve the objective of liberalising national markets. But our fieldwork suggested it is unlikely to yield significant results in this area or indeed in the building of a genuine AFSJ. 